\title{
SARS-CoV-2: is it present in the conjunctiva?
}

\section{SARS-CoV-2: ¿está presente en la conjuntiva?}

\author{
Héctor J. Pérez-Cano*, Óscar Morales-López, Monserrat Y. Garrido-Santos, and \\ Selma A. Somilleda-Ventura \\ Biomedical research center, Fundación Hospital Nuestra Señora de la Luz I.A.P., Mexico City, Mexico
}

\begin{abstract}
The Orthocoronavirinae family was discovered in the 1960s. These are enveloped viruses with positive single-stranded RNA, and their genome size varies approximately between 26 and $32 \mathrm{~kb}$, being the largest genome for an RNA virus. In Mexico, the first reported case was that of a person from Italy. Taking this first case as day 1, the cases have been increasing and, at the time of writing this article, there were 133,974 infected people and 15,944 deaths. The conjunctiva has been proposed as a route of entry for SARS-CoV-2. However, in a search for coronavirus genetic material in tear and conjunctiva samples, patients who did not show conjunctivitis were negative for the presence of viral genetic material, and only one person was positive, both in tear and conjunctiva samples. Negative results for SARS-CoV-2 RNA in tears and conjunctival secretions could indicate that the virus does not replicate in conjunctival epithelia, but could be present in undetectable amounts, which does not rule out that it can be transmitted through the conjunctiva.
\end{abstract}

Keywords: Conjunctiva. Coronavirus. Tear. Pandemic. SARS-CoV-2.

\section{Resumen}

La familia Orthocoronavirinae fue descubierta en la década de 1960. Son virus envueltos de ARN monocatenario positivo y el tamaño de su genoma varía aproximadamente entre 26 y 32 kb, siendo el más grande para un virus ARN. En México, el primer caso reportado fue el de una persona proveniente de Italia. Tomando este como día 1, los casos se han ido incrementando y, hasta el momento de escribir el presente artículo, se tenían contabilizadas 133,974 personas infectadas y 15,944 decesos. La conjuntiva se ha propuesto como vía de entrada para el SARS-CoV-2. Sin embargo, en una búsqueda de material genético del coronavirus en muestras de lagrima y conjuntiva, los pacientes que no mostraban conjuntivitis resultaron negativos a la presencia de material genético viral, y solo una persona resultó positiva, tanto en muestras de lagrima como de conjuntiva. Los resultados negativos de ARN del SARS-CoV-2 en las lágrimas y las secreciones conjuntivales podría indicar que el virus no se replica en los epitelios conjuntivales, pero podría estar presente en cantidades no detectables, lo que no descarta que pueda ser transmitido a través de la conjuntiva.

Palabras clave: Conjuntiva. Coronavirus. Lágrima. Pandemia. SARS-CoV-2.

\footnotetext{
Correspondence:

*Héctor J. Pérez-Cano

Ezequiel Montes 135

Col. Tabacalera, Del. Cuauhtémoc

CP 06030, Mexico City, Mexico

Date of reception: 12-06-2020

E-mail: drhectorpc@ @otmail.com;

drhectorpc@gmail.com

Date of acceptance: 15-04-2021

DOI: 10.24875/RMOE.M21000182 (http://creativecommons.org/licenses/by-nc-nd/4.0/).
} 


\section{Introduction}

The Orthocoronavirinae family, commonly known as coronavirus, was discovered in the 1960s. They are enveloped viruses with positive single-stranded RNA, and their genome varies approximately between 26 and $32 \mathrm{~kb}^{1}$. They mainly infect vertebrate animals; their presence has been demonstrated mainly in bats, although they have been found in mice, cats, cattle, and dromedaries $^{2}$. Mutations in the viral genome have made it possible for coronaviruses to be transmitted from animals to humans, causing damage to health and the threat of epidemic outbreaks ${ }^{3}$. The different types cause respiratory diseases that range from a mild respiratory syndrome, similar to a cold, to severe acute respiratory syndrome ${ }^{2,4}$. The coronavirus owes its name to its appearance, since photomicrographs show a structure with spicules described as a corona-like shaped ${ }^{5}$. The disease is spread by person-to-person contact through the air when talking, coughing, or sneezing ${ }^{6}$.

\section{Methods}

In this work, we reviewed the new coronavirus that is affecting the whole world, linked to a zoonotic origin and that may have ocular involvement, mainly conjunctivitis. We make a brief general description of the behavior of the pandemic in the world and in Mexico, using the Johns Hopkins University database (available at https://coronavirus.jhu.edu/map.html) and the data of the Federal Government of Mexico (available at https:// coronavirus.gob.mx/datos/), which constantly updates the information. A review of the literature was performed using the PubMed and ScienceDirect databases. In PubMed, the Boolean operators AND and OR were used for the search strategy as follows: "SARSCoV-2 OR Ocular manifestations AND conjunctiva". A Spanish literature search was conducted in the Medigraphic and Scielo databases. Most of the selected articles were published between 2015 and 2020, although some older ones were necessary for general data. The topics were related to the structure of the coronavirus, the sources of transmission, the diagnostic methods, the epidemiology, the management of COVID-19, the forms of prevention and the clinical characteristics.

\section{Results}

We found 257 articles that were filtered by title and content, and we excluded those referring to coronaviruses other than SARS-CoV-2, for a final number of 34 (three of them in Spanish). Due to the little information available to date on the subject, the background and knowledge obtained from other viruses that caused epidemic outbreaks and that belong to the coronavirus family are described below, as well as a brief summary of the epidemiological behavior of SARS-CoV-2.

\section{Background}

In recent years there have been epidemic outbreaks caused by a coronavirus. In 2002, an atypical respiratory disease called SARS (Severe Acute Respiratory Syndrome) was described, and by 2003 more than 8,000 patients had been diagnosed in 30 countries, with more than 900 deaths (the average fatality reported was $10 \%$ ). The identified virus was named SARS-CoV ${ }^{4,7}$.

In 2012, a respiratory illness was detected in Saudi Arabia that caused fever, cough, shortness of breath, and pneumonia, and that progressed to acute respiratory failure, multi-organ failure, and death. This disease was caused by a new coronavirus, identified as $\mathrm{nCoV}$, which was later renamed MERS-CoV (Middle East Respiratory Syndrome-Coronavirus $)^{4,7}$.

In December 2019, a new coronavirus emerged, called 2019-nCoV and later SARS-CoV-2 (Severe Acute Respiratory Syndrome-Coronavirus-2). Its origin was reported in the city of Wuhan, in Hubei, province of China ${ }^{8}$. This virus spread rapidly causing a pandemic; to date (August 2020), more than $23,700,000$ infected people and more than 814,000 deaths have been reported worldwide (https://coronavirus.jhu.edu/map.html).

\section{Cases in Mexico}

In Mexico, the first reported case was of a person coming from Italy. Taking this as day 1 , the cases have been increasing and, until day 180 of the epidemic, there were 568,521 infected people and 61,450 deaths; the lethality rate progressively increased until it stabilized at an average of $10 \%$. The behavior of the infection follows the trend shown in Figure 1.

It has been observed that the infection by SARSCoV-2 is slightly more frequent in men (55-60\%) than in women ${ }^{5}$ (https://coronavirus.gob.mx/datos/). It is known that people infected with SARS-CoV-2 can be asymptomatic or have mild to severe disease, with $60 \%$ of ambulatory patients and $40 \%$ that required hospitalization. Typical signs and symptoms are presented in Table 19-12. Complications such as pneumonia and 


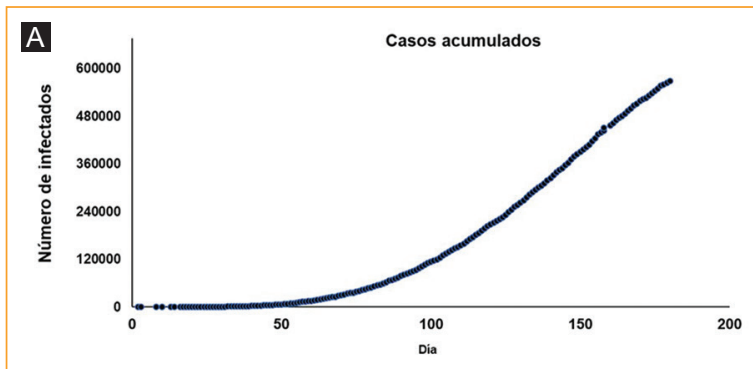

B

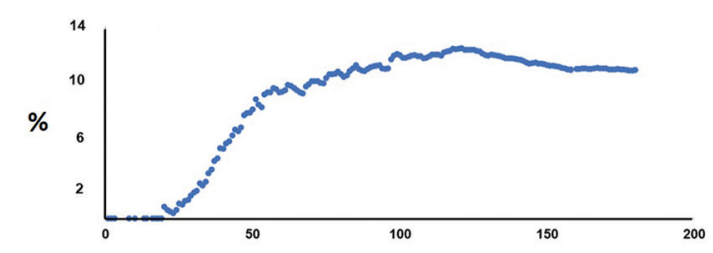

Figure 1. The behavior of the SARS-CoV-2 infection until day 180 after the arrival of the virus to Mexico, from the first patient detected. A: cumulative cases per day (568,521 reported cases). B: lethality rate. Data obtained from https://coronavirus.gob.mx/.

multiple organ dysfunction, occur mainly in older people and in those with chronic diseases such as diabetes, hypertension, cardiovascular conditions, and others that cause immunosuppression ${ }^{8,13,14}$. Interestingly, it has been reported that children show some resistance to the disease, but they represent a risk of viral spread, so it is important to take this into account for containment measures ${ }^{15}$.

\section{Transmission routes}

Since the appearance of SARS-CoV, its transmission routes have been studied, since the virus is present in mucous membranes and secretions, and has also been isolated from feces and urine ${ }^{16-19}$. The cases of contagion have been by close person-to-person contact, defining close contact as people who care for or live with a sick person, and can be due to kissing, hugging, sharing food or drink utensils, or talking at a short distance, and also through a medical examination ${ }^{20}$. With regard to SARS-CoV-2, it is described that it binds to a protein, angiotensin-converting enzyme 2 , which is found on the surface of lung cells, heart, kidneys and in the gastrointestinal tract ${ }^{21,22}$. This enzyme has been reported to be expressed in the corneal, limbal and conjunctival epithelium, which would explain why the eye is an entry point and the reason why some patients show ocular alterations as a clinical manifestation ${ }^{23,24}$.
Table 1. Signs and symptoms of SARS-CoV-2 infection

\begin{tabular}{|l|c|}
\hline Sign or symptom & Presentation in patients \\
\hline Fever & $88 \%$ \\
\hline Dry cough & $68 \%$ \\
\hline Fatigue & $38 \%$ \\
\hline Sputum production & $33 \%$ \\
\hline Difficulty breathing & $19 \%$ \\
\hline Sore throat & $14 \%$ \\
\hline Headache & $14 \%$ \\
\hline Myalgia or arthralgia & $15 \%$ \\
\hline Shaking chills & $11 \%$ \\
\hline Nausea or vomiting & $5 \%$ \\
\hline Nasal congestion & $5 \%$ \\
\hline Diarrhea & $4 \%$ \\
\hline Hemoptysis & $0.9 \%$ \\
\hline Conjunctival congestion & $0.8 \%$ \\
\hline
\end{tabular}

The tears have been considered a fluid that can potentially carry the coronavirus, but this is still debated since studies have not been conclusive regarding the presence of the virus in tears or the conjunctiva ${ }^{20,25-27}$.

On the other hand, the ocular surface has been estimated as 1600 to $1869 \mathrm{~mm}^{2}$ in each eye, including the cornea, which represents a maximum absorption area of approximately $3738 \mathrm{~mm}^{2}$, including the tarsal conjunctiva and the eyelid cul-de-sac. We know that tear production helps to avoid the entrance of foreign material, including microorganisms, and it has also been shown that eyelashes divert air flows and thus control the entry of particles. Deficiency in these mechanisms could increase the risk of infection ${ }^{28}$.

\section{Coronavirus in the conjunctiva}

Since the start of the new SARS-CoV-2 pandemic, ophthalmology has played an important role in monitoring the behavior of the disease. Dr. Li Wenliang, an ophthalmologist at Wuhan Central Hospital, warned about the possible outbreak of a SARS-like disease after treating patients with ocular involvement and symptoms of respiratory failure ${ }^{28}$. The identification of the use of angiotensin-converting enzyme 2 by coronaviruses has provided information on the permissiveness 
of ocular tissue to infection by these viruses; however, although the information for SARS-CoV-2 is still scarce, we can see that the behavior of the viruses belonging to this family is similar ${ }^{21}$.

To try to answer the question of whether SARSCoV-2 resides in the conjunctiva we can review what is known about other viruses. For example, at the end of the SARS-CoV crisis, a new human coronavirus was identified, HCoV-NL63, which was isolated from a 7-month-old boy with bronchiolitis and conjunctivitis ${ }^{29}$. Vabret, et al..$^{30}$ reported that $17 \%$ of patients with HCoVNL63 developed conjunctivitis, but to date there are no studies detailing the mechanisms of infection in ocular tissues ${ }^{31}$. Chan, et al. ${ }^{25}$ reported that 5 out of 17 patients were positive for SARS-CoV using the reverse transcription polymerase chain reaction (RT-PCR) technique in nasopharynx samples, but the virus could not be detected in conjunctival scraping samples or isolated in culture.

Regarding SARS-CoV-2, Wu, et al. ${ }^{27}$ studied 38 patients who, in addition to respiratory symptoms, had epiphora, conjunctival congestion and chemosis. The presence of viral genetic material was determined by RT-PCR, and positivity of $91 \%$ was found in nasopharyngeal swab samples, while only $16.7 \%$ of conjunctival swab samples were positive.

$\mathrm{Xia}$, et al. ${ }^{29}$ carried out a search for SARS-CoV-2 genetic material using RT-PCR in samples of tears and conjunctiva from 30 patients, and obtained two samples at different time points (interval of 2 to 3 days). Twenty-nine of these patients did not show conjunctivitis and were negative for the presence of viral genetic material; only one patient was positive for SARS-CoV-2 in both tears and conjunctiva.

Deng, et al. ${ }^{32}$ reported data from an animal model that consisted of the inoculation of SARS-CoV-2 in the conjunctiva of rhesus monkeys (Macaca mulatta), and detected SARS-CoV-2 in conjunctival swabs only on the first day after inoculation, while in nasal and pharyngeal swabs the virus was detected up to 7 days after inoculation. The results suggest that the probability of contagion of SARS-CoV-2 is higher through the nose and throat than through the conjunctiva. However, the virus could be carried by tears through the tear duct to cause respiratory tract infection.

\section{Discussion}

It has been observed that people infected by any coronavirus may have ocular manifestations, mainly conjunctivitis, suggesting that the virus may be located at the ocular level and would constitute a risk of transmission; however, studies that evaluated the presence of viral genetic material have had low positive results, with positivity ranges from $0 \%$ to $16.7 \%{ }^{29-32}$. It has been speculated that viral absorption through ocular tissues is faster compared to other tissues, so that the presence of the virus in the conjunctiva could last for a short period of time but cause the inflammatory response and ocular manifestations that are longer lasting. The most widely accepted hypothesis so far is that the conjunctival route is not preferred by SARS-CoV-2 and that tear drainage could be involved in the low adherence of viral particles to the conjunctival epithelium, having a "washing" effect and leading the virus to the tear duct to later enter the respiratory tract ${ }^{28,32}$. Although these data suggest that the risk of transmission of SARSCoV-2 through the conjunctiva is very low, the risk exists and must be considered. It has been observed that ophthalmologists are at high risk of infection, not by transmission due to the presence of the virus in the conjunctiva of patients, but by close contact due to the short distance between doctors and patients during ocular examination, so it is necessary to take into account the use of suitable protective equipment during consultations ${ }^{33}$.

Negative results for SARS-CoV-2 RNA in tears and conjunctival secretions could indicate that the virus does not replicate in conjunctival epithelia, but may be present in undetectable amounts, which does not rule out that it can be transmitted through this route ${ }^{29-31}$. The limitations of the reports described are that the studies have small sample sizes and do not exclude the possibility of false-negative results. If the samples were larger, sensitivity could increase, and on the other hand it is important to rule out that the virus and its genetic material are only present for a short time, so it is necessary to carry out an investigation to corroborate this hypothesis. Another important aspect is to verify both the sensitivity and specificity of the tests to detect viral RNA, as well as the sample transport systems, since it must not be forgotten that RNA is a very labile material and this could be contributing to false negative results $^{34}$.

\section{Conclusions}

The route of entry for SARS-CoV-2 is primarily through the eyes, nose, and throat. However, the data suggest that the infection does not establish in the conjunctival epithelium, but rather that the virus is transported to the nasal cavity through the tear duct. It 
is important to consider that conjunctivitis may be a presentation of SARS-CoV-2 disease and that, despite negative results in the conjunctiva, the potential transmission through the ocular surface should not be ignored.

Is the coronavirus present in the conjunctiva? It could be that, as a route of entry, its presence is momentary and passes into the respiratory tract through the tear duct, but the question is not completely answered and further investigation is necessary.

\section{Funding}

This research has not received specific aid from public sector agencies, commercial or non-profit entities.

\section{Conflicts of interest}

The authors have no conflicts of interest to disclose with respect to this review.

\section{Ethical disclosures}

Protection of human and animal subjects. The authors declare that no experiments were performed on humans or animals for this study.

Confidentiality of data. The authors declare that no patient data appear in this article.

Right to privacy and informed consent. The authors declare that no patient data appear in this article.

\section{References}

1. Cui J, Li F, Shi ZL. Origin and evolution of pathogenic coronaviruses. Nat Rev Microbiol. 2019;17:181-92.

2. Hu B, Ge X, Wang LF, Shi Z. Bat origin of human coronaviruses. Virol J. 2015;12:221.

3. Siddell SG, Anderson R, Cavanagh D, Fujiwara K, Klenk HD, Macnaughton MR, et al. Coronaviridae. Intervirology. 1983;20:181-9.

4. de Wit E, van Doremalen N, Falzarano D, Munster VJ. SARS and MERS: recent insights into emerging coronaviruses. Nat Rev Microbiol. 2016; 14:523-34.

5. Gorbalenya AE, Snijder EJ, Spaan WJM. Severe acute respiratory syndrome coronavirus phylogeny: toward consensus. J Virol. 2004;78:7863-6.

6. Oxford JS, Bossuyt S, Lambkin R. A new infectious disease challenge: Urbani severe acute respiratory syndrome (SARS) associated coronavirus. Immunology. 2003;109:326-8.

7. Mackay IM, Arden KE. MERS coronavirus: diagnostics, epidemiology and transmission. Virol J. 2015;12:222.

8. Mo $P$, Xing $Y$, Xiao Y, Deng L, Zhao Q, Wang $H$, et al. Clinical characteristics of refractory COVID-19 pneumonia in Wuhan, China. Clin Infect Dis. 2020. Mar 16:ciaa270. doi: 10.1093/cid/ciaa270. Online ahead of print.

9. Peng $Y$, Zhou YH. Is novel coronavirus disease (COVID-19) transmitted through conjunctiva? J Med Virol. 2020;92:1408-9.
10. Jin X, Lian JS, Hu JH, Gao J, Zheng L, Zhang YM, et al. Epidemiological, clinical and virological characteristics of 74 cases of coronavirus-infected disease 2019 (COVID-19) with gastrointestinal symptoms. Gut. 2020; 69:1002-9.

11. Kannan S, Shaik Syed Ali P, Sheeza A, Hemalatha K. COVID-19 (novel coronavirus 2019) - recent trends. Eur Rev Med Pharmacol Sci. 2020;24:2006-11.

12. Madabhavi I, Sarkar M, Kadakol N. COVID-19: a review. Monaldi Arch Chest Dis. 2020;90(2).

13. Devaux CA, Rolain JM, Raoult D. ACE2 receptor polymorphism: susceptibility to SARS-CoV-2, hypertension, multi-organ failure, and COVID-19 disease outcome. J Microbiol Immunol Infect. 2020;53:425-35.

14. Atluri S, Manchikanti L, Hirsch JA. Expanded umbilical cord mesenchymal stem cells (UC-MSCs) as a therapeutic strategy in managing critically ill COVID-19 patients: the case for compassionate use. Pain Physician. 2020;23:E71-83.

15. Cheng ZJ, Shan J. 2019 Novel coronavirus: where we are and what we know. Infection. 2020;48:155-63.

16. Peng $X, X u X, L i$ Y, Cheng $L$, Zhou $X$, Ren B. Transmission routes of 2019-nCoV and controls in dental practice. Int J Oral Sci. 2020;12:9.

17. Ge ZY, Yang LM, Xia JJ, Fu XH, Zhang YZ. Possible aerosol transmission of COVID-19 and special precautions in dentistry. J Zhejiang Univ Sci B. 2020;21:361-8.

18. Setti L, Passarini F, De Gennaro G, Barbieri P, Perrone MG, Borelli M, et al. Airborne transmission route of COVID-19: why 2 meters/ 6 feet of inter-personal distance could not be enough. Int $\mathrm{J}$ Environ Res Public Health. 2020;17:2932.

19. Chen Y, Chen L, Deng Q, Zhang G, Wu K, Ni L, et al. The presence of SARS-CoV-2 RNA in the feces of COVID-19 patients. J Med Virol. 2020;92:833-40.

20. Hernández G. SARS: epidemiología y mecanismos de transmisión. Med Intensiva 2003;27:686-91.

21. Cano F, Gajardo M, Freundlich M. Eje renina angiotensina, enzima convertidora de angiotensina 2 y coronavirus. Rev Chil Pediatr. 2020;91:330-8.

22. Soler MJ, Lloveras J, Batlle D. Enzima conversiva de la angiotensina 2 y su papel emergente en la regulación del sistema renina-angiotensina. Med Clin (Barc). 2008;131:230-6.

23. Zhou L, Xu Z, Castiglione GM, Soiberman US, Eberhart CG, Duh EJ. ACE2 and TMPRSS2 are expressed on the human ocular surface, suggesting susceptibility to SARS-CoV-2 infection. Ocul Surf. 2020;18:537-44.

24. Collin J, Queen R, Zerti D, Dorgau B, Georgiou M, Djidrovski I, et al. Co-expression of SARS-CoV-2 entry genes in the superficial adult human conjunctival, limbal and corneal epithelium suggests an additional route of entry via the ocular surface. Ocul Surf. 2021;19:190-200.

25. Chan WM, Yuen KS, Fan DS, Lam DS, Chan PK, Sung JJ. Tears and conjunctival scrapings for coronavirus in patients with SARS. $\mathrm{Br} \mathrm{J}$ Ophthalmol. 2004;88:968-9.

26. Seah I, Agrawal R. Can the coronavirus disease 2019 (COVID-19) affect the eyes? A review of coronaviruses and ocular implications in humans and animals. Ocul Immunol Inflamm. 2020;16:1-5.

27. Wu P, Duan F, Luo C, Liu Q, Qu X, Liang L, et al. Characteristics of ocular findings of patients with coronavirus disease 2019 (COVID-19) in Hubei Province, China. JAMA Ophthalmol. 2020;138:575-8.

28. Coroneo MT. The eye as the discrete but defensible portal of coronavirus infection. Ocul Surf. 2021;19:176-82.

29. Xia J, Tong J, Liu M, Shen Y, Guo D. Evaluation of coronavirus in tears and conjunctival secretions of patients with SARS-CoV-2 infection. J Med Virol. 2020;92:589-94.

30. Vabret A, Mourez T, Dina J, van der Hoek L, Gouarin S, Petitjean J, et al. Human coronavirus NL63, France. Emerg Infect Dis. 2005;11:1225-9.

31. Durán CSC, Mayorga GDC. The eye: "An organ that must not be forgotten in coronavirus disease 2019 (COVID-2019) pandemic". J Optom. 2020;14:114-9.

32. Deng W, Bao L, Gao H, Xiang Z, Qu Y, Song Z, et al. Rhesus macaques can be effectively infected with SARS-CoV-2 via ocular conjunctival route. bioRxiv. 2020. Disponible en: https://www.biorxiv.org/conten$\mathrm{t} / 10.1101 / 2020.03 .13 .990036 \mathrm{v} 1$

33. Li JO, Lam DSC, Chen Y, Ting DSW. Novel coronavirus disease 2019 (COVID-19): the importance of recognising possible early ocular manifestation and using protective eyewear. Br J Ophthalmol. 2020;104:297-8.

34. Scohy A, Anantharajah A, Bodéus M, Kabamba-Mukadi B, Verroken A, Rodriguez-Villalobos $\mathrm{H}$. Low performance of rapid antigen detection test as frontline testing for COVID-19 diagnosis. J Clin Virol. 2020;129:104455. 